\title{
Analysis of the existing methodological approaches to the problem of establishing the boundaries of soil pollution with the main pollutants and metal-containing nanoparticles in the areas of location of unauthorized dumps
}

\author{
I.O. Tuktarova ${ }^{1 *}$ (iD, R.A. Bolotov ${ }^{1,2}$ (iD \\ ${ }^{1}$ Ufa State Petroleum Technological University, Ufa, Bashkortostan Republic, Russia \\ ${ }^{2}$ South-Ural Interregional Directorate of the Federal Service for Supervision of Natural Resources Management \\ of Russian Federation, Ufa, Republic of Bashkortostan, Russia
}

* Corresponding author: e-mail:umrko@mail.ru

\begin{abstract}
Introduction. Unauthorized dumps are territories that are not permitted and not equipped in accordance with the current legislation of the territory, where waste products are disposed of. Most of the unauthorized dumps, both industrial and municipal solid waste (MSW), are objects of accumulated harm. In connection with the increase in the use of nanoparticles of various genesis in engineering materials, there is a need to assess their impact on environmental components and human health. One of the main marker substances that determine the ecotoxicological effect of dumps are heavy metals, including those entering the environment in the form of metal-containing nanoparticles. Their identification, determination of the processes of horizontal and vertical migration of pollutants $(\mathrm{P})$, identification of the intensity of negative processes are necessary information for making decisions on the choice of methods and technologies for recultivation of disturbed areas. Currently, there are no legislative acts (LA) that take into account the specifics of such objects in the study of territories within the framework of environmental surveys (ES), which necessarily precede the implementation of project documentation for recultivation. A vital task is to develop a methodological approach to diagnosing the state of territories disturbed as a result of waste disposal, and to reliably determine the boundaries of soil pollution, taking into account modern trends in the development of nanotechnology. Methods and materials. The analytical study was based on the results of environmental surveys at four unauthorized dumps of the Republic of Bashkortostan (three dumps for municipal solid waste (MSW) and one dump for industrial waste), carried out in 2019-2020. Results and discussion. A study of the reliability and completeness of determining the level of soil pollution in the territory of the dumps was made. Deviations from the requirements of CS 11-102-97, GOST 17.4.3.01-83 in terms of the number of sampling points and their spatial location were revealed. It was found that the requirements of Article 1 and Article 80.1 of the Federal Law of 10.01.2001 No.7-FL "On Protection of Environment" on identifying negative environmental changes and establishing the ability of pollutants to migrate to other components of the environment were not taken into account. Conclusions. The existing methodological approaches to establishing the boundaries of soil pollution in the areas where unauthorized dumps are located require revision and specification.
\end{abstract}

KEY WORDS: waste, unauthorized dumps, soils, pollutants, metal nanoparticles, environmental surveys (ES), environment.

FOR CITATION: Tuktarova I.O., Bolotov R.A. Analysis of the existing methodological approaches to the problem of establishing the boundaries of soil pollution with the main pollutants and metal-containing nanoparticles in the areas of location of unauthorized dumps. Nanotechnologies in Construction. 2021; 13(3): 193-200. Available from: doi: 10.15828/2075-8545-2021-13-3-193-200.

\section{INTRODUCTION}

$\mathrm{U}$ nauthorized dumps are one of the most common objects of accumulated harm (negative impact resulting from past economic and other activities, the obligations to eliminate which were not fulfilled or were not fulfilled in full) and sources of a whole spectrum of pollutants entering the environment [1-4].

According to the Federal Target Program "Elimination of Accumulated Environmental Damage" for

(c) Tuktarova I.O., Bolotov R.A., 2021 
2014-2025 [5], as a result of economic activity, 31.6 billion tons of waste have been accumulated in the Russian Federation by now, of which $2-2.3$ billion tons are toxic. Of the 121 particularly hazardous objects of accumulated environmental harm on the territory of the Russian Federation included in the register, 69 are dumps and waste landfills [6].

The specificity of unauthorized dumps as objects of pollution, first of all, is the lack of information about the waste disposed on them, and, as a consequence, the unpredictability of the nature and levels of impact. On the territories of unauthorized dumps, the status and composition of MSW is not monitored, and the established period for the placement of MSW is not observed [7].

In this case, the main component of the environment, experiencing a negative effect, are soils in which the morphological and physical properties deteriorate, the water, air, thermal and redox regimes are disturbed, the conditions necessary for the existence of soil animals and microorganisms, the growth and development of plants change.

As studies show [8], under soil pollution, the soil matrix system and the associated work of all nanoreactors are significantly affected. At the same time, nanotechnological processes in soils (the formation of aggregates, humus, litter, etc.), which are directly related to soil fertility, are not taken into account in the system of environmental regulation, although they could provide decisive information about the degree of degradation of soil ecosystems.

The soil is the main accumulator of technogenic nanoparticles entering the environment as a result of economic and other activities. Technogenic metal nanoparticles in soil are mainly represented by the following compounds $\mathrm{TiO}_{2}, \mathrm{ZnO}, \mathrm{AlO}, \mathrm{CuO}, \mathrm{Ag}, \mathrm{MgO}, \mathrm{FeO}_{x}, \mathrm{NiO}$, $\mathrm{MnO}_{\mathrm{x}}$ [9-13]. The sources of their entry from dumps into soils are waste of packaging materials, household chemicals, agrochemicals, spent industrial catalysts, ash from thermal waste disposal, etc.

In the structure of normative legal acts [14-18], regulating the scope of research to determine the admissibility of negative impact on soils, we are faced with the traditionally accepted definition of the degree of degradation by the level of chemical pollution.

This approach does not take into account the possibility of joint action of harmful factors, the dependence of the impact on the symbaticity of factors, and the determination of environmental risks, and, moreover, the determination of the form of chemical compounds (mobile, immobile, macrodispersed, nanoparticles, etc.).

And while chemical pollution of soils and grounds within the framework of ES is assessed by the total indicator $(\mathrm{Zc})$, which takes into account the additivity of pollutants, it is an indicator of the adverse impact only on the health of the population.
This methodological approach is complicated by the lack of requirements to the scope of research during surveys (the number of samples) for such complex objects as unauthorized dumps, accordingly, it becomes difficult to determine the zones of influence of objects and the degree of soil degradation.

According to RP 1.2.2639-10 "Use of methods for quantitative determination of nanomaterials at nanoindustry enterprises" [19], it is recommended to determine the presence of nanoparticles in environmental components (atmospheric air, water bodies, soils) in a number of controlled objects. The presence of this document reflects the importance of an integrated approach to identifying the degree and nature of contamination.

Within the framework of the state environmental expertise, all the above points are of particular importance, since materials on environmental impact assessment should be scientifically substantiated, reliable and reflect the results of research carried out taking into account the relationship of various environmental factors [20].

\section{METHODS AND MATERIALS}

This work was based on the results of the ES analysis for 2019-2020 in terms of the reliability and completeness of determining the level of soil pollution in the territory of the location of four unauthorized dumps of the Republic of Bashkortostan. The study of the compliance of the ES materials with the requirements of the current regulatory documentation for geoecological soil testing was carried out.

Dump № 1 is an unauthorized MSW dump. The year of the beginning of the exploitation of the dump is 1993 . The landfill body is a mixture of MSW covered with layers of insulating soil. The proposed waste storage system is based on the maps using the thrust method.

Dump № 2 is an unauthorized MSW dump. The dump body is an embankment with steep slopes, partly overgrown with weeds. There are no intermediate layers of insulating primer in the body of the dump.

Dump № 3 - Industrial waste dump. The beginning of waste storage - 1970s. The dump is an open pit where solid and resinous wastes (various spent catalysts containing heavy metals) were stored and liquid heavy hydrocarbons were placed in technological maps.

Dump № 4 is an unauthorized MSW dump. The dump body is an embankment of garbage, mainly covered with soil and overgrown with weeds of the grass layer.

\section{RESULTS AND DISCUSSIONS}

The first question that we face when assessing the sufficiency of the ES materials is the number and spatial location of the samples taken (determining the completeness and representativeness of research results). 
In clause 4.19 of the Code specification CS 11-10297 [14], a reference is provided to GOST 17.4.3.01-83 "Environmental protection. Soils. General requirements for sampling" [15], which contains the following recommendation on the number of samples: at least one combined sample per $0.5-1.0$ hectares with a heterogeneous soil cover and at least one combined sample per 1.0-5, 0 ha - with uniform. Scope [15] - for general and local pollution.

Further, according to the text of clause 4.19 [14], it is indicated that the number and location of samples, as well as the distance between samples, are set in the survey program depending on the type and purpose of the projected object, the natural and technogenic conditions of the research area and the stage of design and survey work.

Table 1 shows the features of the dumps under consideration that affect the spread of pollutants in the soil profile and the possibility of the occurrence of foci of secondary soil pollution.

Clause 4.16 [14], which establishes the requirements for assessing pollution in the zone of influence of economic objects, also gives a reference to the survey program: "The location of sampling points is established in the survey program depending on the expected structure of the pollution field, the geological structure of the territory."

Thus, the quality of the work is directly related to the responsibility of the Customer, who draws up the Terms of Reference for the ES. In ES, for all objects in the survey programs, the scope of work is limited and/or tied to the "territory of the object location" in accordance with the data of the development plan for a land plot [21].

In this context, many legal restraints arise, and sampling in adjacent areas is, at best, carried out only within the sanitary protection zones (SPZ) of the facilities. Although soil pollution at landfill sites is often secondary, some of the pollutants are washed out with precipitation and groundwater, ensuring the accumulation of pollutants at a certain distance from the objects [22-24].

The same clause 4.16 [14] regulates that "the adopted sampling system should ensure the study of the pollutional zone in plan and in vertical section by the main components of the environment, identification of pollution sources, migration routes, areas and fluxes of dispersion and accumulation of pollutants".

As you can see from the table 2, the number of sampling points (sites) does not meet the requirements of [14, 15] in terms of completeness of research: the sampling

\section{Table 1}

\section{General data on research objects}

\begin{tabular}{|l|l|l|l|l|}
\hline \multicolumn{1}{|c|}{ Indicator name } & \multicolumn{1}{|c|}{ Dump № 1 } & \multicolumn{1}{|c|}{ Dump № 2 } & \multicolumn{1}{c|}{ Dump № 3 } & \multicolumn{1}{c|}{ Dump № 4 } \\
\hline Dump area, ha & 18,12 & 12,05 & 4,13 & 10,07 \\
\hline $\begin{array}{l}\text { Volume (mass) of } \\
\text { accumulated waste }\end{array}$ & $1434369 \mathrm{~m}^{3}$ & $442472 \mathrm{~m}^{3}$ & $30000 \mathrm{t}$ & $850000 \mathrm{~m}^{3}$ \\
\hline $\begin{array}{l}\text { Features of hydro- } \\
\text { geological conditions }\end{array}$ & Wetland area & Wetland area & - & $\begin{array}{l}\text { Wetland area, confined } \\
\text { groundwater }\end{array}$ \\
\hline $\begin{array}{l}\text { Existence of exceed- } \\
\text { ing the MAC for } \\
\text { pollutants in ground } \\
\text { (underground wa- } \\
\text { ters) }\end{array}$ & Not available & $\begin{array}{l}\text { Sulfate ion, calcium, } \\
\text { magnesium, lithium }\end{array}$ & $\begin{array}{l}\text { Benz (a) pyrene, } \\
\text { phenol, nickel }\end{array}$ & $\begin{array}{l}\text { BOD, dry residue, chloride } \\
\text { ion, chromium, lead, iron, } \\
\text { cadmium, magnesium, } \\
\text { mercury, barium, lithium, } \\
\text { petroleum products }\end{array}$ \\
\hline $\begin{array}{l}\text { Existence of exceed- } \\
\text { ing the MAC for } \\
\text { pollutants in surface } \\
\text { water bodies (includ- } \\
\text { ing bottom sedi- } \\
\text { ments) }\end{array}$ & $\begin{array}{l}\text { BOD, suspended } \\
\text { solids }\end{array}$ & $\begin{array}{l}\text { Copper, arsenic, } \\
\text { chromium, mercury, } \\
\text { lead, petroleum } \\
\text { products }\end{array}$ & $\begin{array}{l}\text { Benz (a) pyrene, } \\
\text { phenols, nitrate } \\
\text { ions }\end{array}$ & $\begin{array}{l}\text { Copper, arsenic, chromi- } \\
\text { um, mercury, lead, petro- } \\
\text { leum products }\end{array}$ \\
\hline $\begin{array}{l}\text { The presence of } \\
\text { leachate in the body } \\
\text { of the dump }\end{array}$ & Yes & No & No & Yes \\
\hline $\begin{array}{l}\text { Soil type of the sur- } \\
\text { rounding area }\end{array}$ & $\begin{array}{l}\text { Urbanozems, } \\
\text { carbonate cher- } \\
\text { nozems }\end{array}$ & $\begin{array}{l}\text { Urbanozems, cher- } \\
\text { nozems, leached } \\
\text { medium humus me- } \\
\text { dium thick }\end{array}$ & $\begin{array}{l}\text { Urbanozems, } \\
\text { leached cherno- } \\
\text { zems }\end{array}$ & $\begin{array}{l}\text { Urbanozems, leached cher- } \\
\text { nozems }\end{array}$ \\
\hline
\end{tabular}


Table 2

The scope of research within the framework of the ES to establish soil pollution in the areas of dumps

\begin{tabular}{|c|c|c|c|c|}
\hline Indicator name & Dump № 1 & Dump № 2 & Dump № 3 & Dump № 4 \\
\hline $\begin{array}{l}\text { Study area } \\
\text { boundaries }\end{array}$ & $\begin{array}{l}\text { Within the SPZ } \\
\text { ( } 500 \mathrm{~m} \text { from the bor- } \\
\text { der of the dump) }\end{array}$ & $\begin{array}{l}\text { Within the SPZ } \\
\text { (115 } \mathrm{m} \text { from the bor- } \\
\text { der of the dump) }\end{array}$ & $\begin{array}{l}\text { Within the SPZ } \\
\text { (1000 } \mathrm{m} \text { from the } \\
\text { border of the dump) }\end{array}$ & $\begin{array}{l}\text { Within the SPZ } \\
\text { ( } 320 \mathrm{~m} \text { from the bor- } \\
\text { der of the dump) }\end{array}$ \\
\hline $\begin{array}{l}\text { Number of sampling } \\
\text { points and/or sam-- } \\
\text { ple ares (SA) }\end{array}$ & $\begin{array}{l}5 \text { wells along the pe- } \\
\text { rimeter of the dump } \\
\text { body, } 4 \text { SA within a } \\
\text { radius of } 50 \mathrm{~m} \text { from } \\
\text { the dump body }\end{array}$ & $\begin{array}{l}3 \mathrm{SA} \text { within a radius } \\
\text { of } 50 \mathrm{~m} \text { from the } \\
\text { dump body }\end{array}$ & $\begin{array}{l}3 \text { wells within a ra- } \\
\text { dius of } 100 \mathrm{~m} \text { from } \\
\text { the dump body }\end{array}$ & $\begin{array}{l}5 \text { wells along the pe- } \\
\text { rimeter of the dump } \\
\text { body, } 3 \text { SA within } \\
\text { a radius of } 50 \mathrm{~m} \text { from } \\
\text { the dump body }\end{array}$ \\
\hline Number of samples & $\begin{array}{l}20 \text { well samples layer } \\
\text { by layer } \\
4 \text { pooled samples } \\
\text { (envelope method } \\
\text { with SA) }\end{array}$ & $\begin{array}{l}3 \text { pooled samples } \\
\text { (envelope method) } \\
\text { with SA }\end{array}$ & $\begin{array}{l}18 \text { well samples layer } \\
\text { by layer }\end{array}$ & $\begin{array}{l}20 \text { well samples layer } \\
\text { by layer } \\
4 \text { pooled samples } \\
\text { (envelope method } \\
\text { with SA) }\end{array}$ \\
\hline Vertical depth survey & $\begin{array}{l}0.0-3.0 \mathrm{~m} \text { layer by } \\
\text { layer in wells } \\
0.0-0.2 \mathrm{~m} \text { on SA }\end{array}$ & $0.0-0.2 \mathrm{~m}$ on SA & $\begin{array}{l}0.3-15.0 \mathrm{~m} \text { layer by } \\
\text { layer in wells }\end{array}$ & $\begin{array}{l}0,0-3,0 \mathrm{~m} \text { layer by } \\
\text { layer in wells } \\
0,0-0,2 \mathrm{~m} \text { on } \mathrm{SA}\end{array}$ \\
\hline $\begin{array}{l}\text { Presence of a base- } \\
\text { line sample taken } \\
\text { outside the sphere of } \\
\text { local anthropogenic } \\
\text { impact }\end{array}$ & No & No & No & Yes \\
\hline $\begin{array}{l}\text { Assessment of soil } \\
\text { fertility }\end{array}$ & No & No & No & Yes \\
\hline $\begin{array}{l}\text { Analysis of pollution } \\
\text { by toxic-chemical } \\
\text { indicators }\end{array}$ & $\begin{array}{l}\text { Nickel, copper, zinc, } \\
\text { lead, cadmium, arse- } \\
\text { nic, mercury, cobalt, } \\
\text { manganese, chro- } \\
\text { mium, petroleum } \\
\text { products, benz (a) } \\
\text { pyrene }\end{array}$ & $\begin{array}{l}\text { Nickel, copper, zinc, } \\
\text { lead, cadmium, arse- } \\
\text { nic, mercury, cobalt, } \\
\text { petroleum products, } \\
\text { benzo (a) pyrene }\end{array}$ & $\begin{array}{l}\text { Nickel copper, zinc, } \\
\text { lead, cadmium, arse- } \\
\text { nic, mercury, petro- } \\
\text { leum products, benz } \\
\text { (a) pyrene }\end{array}$ & $\begin{array}{l}\text { Nickel, copper, zinc, } \\
\text { lead, cadmium, arse- } \\
\text { nic, mercury, man- } \\
\text { ganese, chromium, } \\
\text { cobalt, petroleum } \\
\text { products, benzo (a) } \\
\text { pyrene }\end{array}$ \\
\hline $\begin{array}{l}\text { Determination of } \\
\text { mobile forms of } \\
\text { metals }\end{array}$ & No & No & No & No \\
\hline $\begin{array}{l}\text { Determination } \\
\text { of nanoparticles, } \\
\text { including metal- } \\
\text { containing ones }\end{array}$ & No & No & No & No \\
\hline $\begin{array}{l}\text { Dump base soil sur- } \\
\text { veys }\end{array}$ & Absent & Absent & 4 points & 2 points \\
\hline
\end{tabular}

depth was chosen incorrectly. In case of chronic anthropogenic impact (from 30 to 50 years for research objects), which develops at unauthorized dumps, it is unacceptable to analyze only the surface layer, soil sampling should be carried out in each engineering-geologic element.

According to the table 1, pollution of surface and ground waters is present in all objects, which, when analyzed together with soil research data (table 2), can only indicate that the soil control points were chosen incorrectly, and migration routes and reliable depth of pollutant accumulation have not been established.

An important point showing the quality of research work is the definition, along with the bulk forms of metals, their mobile forms. The amount of mobile metal compounds is used to assess the amount of trace elements available to plants, as well as the ecological state 
of contaminated soils. The main mechanisms of the action of mobile forms on the soil are complexation and ion exchange. It has been established that the form of input of heavy metals into the soil significantly affects the transformation of technogenic compounds and their distribution [25], namely, heavy metals are the main pollutants entering the environment components from waste disposal facilities [26].

Currently, there are not many studies to determine the migration paths of nanoparticles in soils and to determine their role in the degradation of soil ecosystems. However, it was established [9] that natural soil colloids are carriers of metal nanoparticles through soil profiles. The main trends in the distribution of metal-containing nanoparticles have a similar picture with the distribution of other pollutants in soils, while the nanoparticles have a higher migration ability and bioavailability.

Soil quality control by chemical parameters and determination of the degree of hazard was carried out in accordance with SanPiN 2.1.7.1287-03 "Sanitary- epidemiological requirements for soil quality" [27], which set requirements for the quality of soils in populated areas and agricultural land (table 3). An additive assessment of the degree of chemical pollution of soil and ground at the survey sites was carried out on the basis of the total indicator of chemical pollution $\left(Z_{c}\right)$, which is an indicator of adverse impact on the population.
In the context of unauthorized dumps, it is important not only to comply with hygienic standards, but also to take into account other criteria for the functioning of ecosystems: the enzymatic activity of soil microbiota, potential fertility, potential phyto- and zootoxicity of soils, and the intensity of nanotechnological soil processes. It is they which can provide reliable information on the magnitude of environmental risk and a long-term forecast for the restoration of territories, that can directly affect technological solutions for eliminating the negative impact on the environment and reclamation of disturbed lands.

Another approach to comparing and assessing the levels of chemical pollution is to compare the concentrations of pollutants with "background" values - the content of analyzed substances in anthropogenically undisturbed natural objects-analogues. However, this approach was not reflected in the ES for three objects out of four analyzed.

Another requirement of CS 11-102-97 [14] in terms of the analyzed pollutants was not taken into account in research at unauthorized dumps: Clause 4.29 regulates soil testing for the content of volatile toxicants (benzene, toluene, xylene, ethylbenzene, chlorinated hydrocarbons, oil and oil products ) and other pollutants that penetrate into subsoil horizons to a depth of $3.0-3.5 \mathrm{~m}$.

In dumps № 1 and 4, studies on petroleum products were carried out to a depth of up to $3.0 \mathrm{~m}$ in wells and up

Table 3

Category of soil pollution according to SanPiN 2.1.7.1287-03 [27]

\begin{tabular}{|c|c|c|c|c|}
\hline \multirow[t]{2}{*}{ Research area } & \multicolumn{4}{|c|}{$\begin{array}{l}\text { Pollution category according to SanPiN 2.1.7.1287-03 } \\
\text { "Sanitary-epidemiological requirements for soil quality" }\end{array}$} \\
\hline & Dump № 1 & Dump № 2 & Dump № 3 & Dump № 4 \\
\hline Dump base soils & - & - & Permissible & Permissible \\
\hline Adjacent area & $\begin{array}{l}\text { Wells: } \\
0.00-0.20 \mathrm{~m} \text { (moderately } \\
\text { dangerous); } \\
0.2-3.0 \mathrm{~m} \text { (permissible) } \\
\text { SA: } \\
\text { moderately dangerous } \\
\text { permissible }\end{array}$ & $\begin{array}{l}\text { SA: } \\
\text { moderately } \\
\text { dangerous } \\
\text { permissible }\end{array}$ & $\begin{array}{l}\text { Wells: } \\
0,3-1,0 \mathrm{~m} ; 1,0-2,0 \mathrm{~m} ; \\
2,0-3,0 \mathrm{~m} ; 3,0-5,0 \mathrm{~m} \\
\text { (permissible); } \\
5,0-10,0 \mathrm{~m} ; 10,0-15,0 \mathrm{~m} \\
\text { (clean) } \\
1,0-2,0 \mathrm{~m} ; 5,0-10,0 \mathrm{~m} \\
\text { (permissible); } \\
0,3-1,0 \mathrm{~m} ; 2,0-3,0 \mathrm{~m} ; \\
3,0-5,0 \mathrm{~m} ; 10,0-15,0 \mathrm{~m} \\
\text { (clean) } \\
1,0-2,0 \mathrm{~m} ; 3,0-5,0 \mathrm{~m} \\
\text { (permissible); } \\
0,3-1,0 \mathrm{~m} ; 2,0-3,0 \mathrm{~m} ; \\
5,0-10,0 \mathrm{~m} ; 10,0-15,0 \mathrm{~m} \\
\text { (clean) }\end{array}$ & SA: permissible \\
\hline
\end{tabular}


to $0.2 \mathrm{~m}$ at the SA, and at dump № $2-$ only at the SA up to $0.2 \mathrm{~m}$. At the industrial waste dump, where organic pollutants could have been disposed of, all petroleum hydrocarbons were accounted for as "petroleum products", although in the context of toxicity and impact on soil processes, aromatic hydrocarbons (benzene), unlike petroleum products, have established MAC values and a higher hazard level [28].

\section{CONCLUSIONS}

Currently, a large scientific and practical experience has been accumulated in the diagnosis of soil ecosystems exposed to unauthorized disposal and disposal of waste. However, the requirements of environmental regulatory documents that determine the composition and structure of research within the framework of ES are more focused on construction objects (rather than elimination of accumulated harm) and compliance with the requirements of hygienic standards in the light of the impact of pollutants on human health. At the same time, the term "negative impact on the environment" in the legislation is defined much broader - as "the impact of economic and other activities, the consequences of which lead to negative changes in the quality of the environment" [29].

With the development of scientific research, new technologies and industries, the list of substances required for diagnosis and control is also expanding. Due to the presence of dissimilar engineering materials in dumps and the formation of special pollution due to the migration of heavy metals, it is recommended to expand approaches to assessing the impact of these objects on the environment, as well as taking into account the ecotoxicological effect of metal-containing nanoparticles.

Currently, the completeness and reliability of research directly depend on the qualifications of the developers of the survey and the requirements of the Customer of the design documentation for the elimination (reclamation) of unauthorized dumps.

The existing methodological approaches to establishing the boundaries of soil pollution in areas where unauthorized dumps are located require revision and specification in terms of:

- requirements for the number and spatial distribution of sampling points, taking into account the specifics of waste disposal facilities;

- requirements for the list of analyzed substances with the establishment of marker substances for each object;

- taking into account the structural, genetic, biochemical characteristics of soils, for which the impact on the environment is assessed;

- taking into account the assessment of the ecological potential of soils, their resistance to impact and the ability to restore.

\section{REFERENCES}

1. Zagorskaya E.P., Chigarev R.I. Illegall dumps are as natural anthropogenic factor in urban areas. News of the Samara Scientific Center of the Russian Academy of Sciences. 2018; 20(5): 593-598.

2. Stepanov E.G., Tuktarova I.O., Malikova T.Sh. Problems of placement of industrial wastes in landfills in the industrial city. Nanotechnologies in Construction. 2017; 9(2): 103-118. Available from: doi: 10.15828/2075-8545-20179-2-103-118.

3. Kulsaitova L.R., Bakhtiyarova R.S., Tuktarova I.F. Analysis of the state of soils on the territory of the waste disposal facility. In: Actual problems of science and technology-2017: Collection of articles, reports and speeches X Intern. scientific-practical conf. young scientists, 14 April - 19 May 2017, Ufa, Russian Federation. Ufa: Publishing house "Petroleum engineering"; 2017. Vol. 1., p. 182-184.

4. Yangirova Z.Z., Tuktarova I.O. Ecogeology of urbanized territories: textbook. Ufa: USPTU Publishing House; 2019.

5. Passport of the Federal Target Program "Elimination of Accumulated Environmental Damage" for 2014-2025 of the Ministry of Natural Resources and Environment of the Russian Federation. Available from: http://biotech2030. ru/wp-content/uploads/2015/03/ФЦП-Ликвидация-накопленного-экологического-ущерба-на-2014-2025. pdf [Accessed 1st March 2021].

6. Ministry of Natural Resources and Environment of the Russian Federation Available from: http://www.mnr. gov.ru/activity/directions/likvidatsiya_nakoplennogo_ekologicheskogo_ushcherba/[Accessed1st March 2021]. 
7. Federal Law of 24.06.1998 No. 89-FZ "On production and consumption wastes" Available from : http://www. consultant.ru/document/cons_doc_LAW_19109/[Accessed 1st March 2021]

8. Zubkova T.A., Karpatchevskiy L.O. Nanotechnologies in soil. Theoretical and applied ecology. 2009; 1: 4-7.

9. Gladkova M.M., Terekhova V.A. Engineering nanomaterials in soil: Sources of entry and migration pathways. Vestn. Moscow un-ty. Ser. 17. Soil science. 2013; 3: 34-39.

10. Xu C., Peng C., Sun L., Zhang S., Huang H., Chen Y., J. Shi. Distinctive effects of $\mathrm{TiO}_{2}$ and $\mathrm{CuO}$ nanoparticles on soil microbes and their community structures in flooded paddy soil. Soil Biology and Biochemistry. 2015; 86: $24-33$.

11. Kolesnikov S.I., Timoshenko A.N., Kazeev K.Sh., Akimenko Yu.V. Effects of pollution by nanoparticles of nickel and iron oxides on biological properties of ordinary chernozem. Bulletin of higher education institutes. North Caucasus region. Natural Sciences. 2016; 1(189): 71-75.

12. Andrusishina I.N., Golub I.A., Didikin G.G., Litvin S.E., Gromovoy T.Yu., Gorchev V.F., Movchan V.A. Structure, properties and toxicity of nanoparticles of silver and copper oxides. Biotechnology. 2011; 4(6): 51-59.

13. Tsitsuashvili V.S., Minkina T.M., Nevidomskaya D.G., Rajput V.D., Mandzhieva S.S., Sushkova S.N., Bauer T.V., Burachevskaya M.V. The impact of copper nanoparticles on plants and soil microorganisms (literature review). Don Agrarian Science Bulletin. 2017; 3(39): 93-100.

14. CS 11-102-97 Engineering and environmental surveys for construction Available from: http://docs.cntd.ru/ document/871001220 [Accessed 1st March 2021].

15. GOST 17.4.3.01-83 Environmental protection. Soils. General requirements for sampling. Available from: http://docs.cntd.ru/document/gost-17-4-3-01-83 [Accessed 1st March 2021].

16. GOST 17.4.4.02-2017 Environmental protection. Soils. Methods of sampling and preparation of samples for chemical, bacteriological, helminthological analysis. Available from : http://docs.cntd.ru/document/1200158951 [Accessed 1st March 2021].

17. GOST 28168-89 Soils. Sampling. Available from: http://docs.cntd.ru/document/1200023554.

18. GOST P 53123-2008 (ISO 10381-5:2005) Soil quality. Sample selection. Part 5. Guidance for examining urban and industrial sites for soil contamination. Available from: http://docs.cntd.ru/document/1200074384.

19. The use of methods for the quantitative determination of nanomaterials at the enterprises of the nanoindustry: Methodical recommendations. Moscow: Federal Center for Hygiene and Epidemiology of Rospotrebnadzor; 2010.

20. Order of the State Committee for Ecology of the Russian Federation dated May 16, 2000 No. 372 "On approval of the Regulations on the assessment of the impact of planned economic and other activities on the environment in the Russian Federation". Available from: https://www.consultant.ru/cons/cgi/online.cgi?req=doc\&base=LAW\&n $=27864 \& \mathrm{dst}=1000000001 \% 2 \mathrm{C} 0 \# 08611060435041569$.

21.Urban Planning Codeofthe RussianFederationdatedDecember29,2004No.190-FL.Availablefrom: https://www. consultant.ru/cons/cgi/online.cgi? req $=$ doc\&base $=$ LAW\& $n=373276 \& d s t=1000000001 \% 2 C 0 \# 04225181759092682$.

22. Fedotov P.S., Ermolin M.S., Karandashev V.K., Ladonin D.V. Characterization of size, morphology and elemental composition of nano-, submicron, and micron particles of street dust separated using field-flow fractionation in a rotating coiled column. Talanta. 2014; 130: 1-7.

23. Yearbook. Soil pollution of the Russian Federation with industrial toxicants in 2019. Obninsk: FSBI NPO Typhoon; 2019.

24. Yearbook. Soil pollution of the Russian Federation with industrial toxicants in 2019. Obninsk: FSBI NPO Typhoon; 2020.

25. Ivanova Yu.S., Gorbachev V.N. Heavy metals pollution of soil under the influence of illegal dumping (health and environmental aspects). Ulyanovsk Medico-biological Journal. 2012; 1: 119-124.

26. Zamotaev I.V., Ivanov I.V., Mikheev P.V., Belobrov V.P. Assessment of the state of soils and vegetation in areas of landfills and municipal solid waste sites (a review). Eurasian Soil Science. 2018; 7: 907-924.

27. SanPiN 2.1.7.1287-03 "Sanitary and Epidemiological Requirements for Soil Quality".

28. Hygienic standards HS 2.1.7.2041-06 "Maximum permissible concentrations (MPC) of chemicals in the soil."

29. Federal Law of 10.01.2001 No. 7-FL "On Environmental Protection" http://www.consultant.ru/document/ cons_doc_LAW_34823/bb9e97fad9d14ac66df4b6e67c453d1be3b77b4c/(accessed on 01.03.2021). 


\section{INFORMATION ABOUT THE AUTHORS}

Iren O. Tuktarova, Cand. Sci. (Eng.), Professor, Head of Department «Environmental Protection and Prudent Exploitation of Natural Resources», Ufa State Petroleum Technological University, Ufa, Bashkortostan Republic, Russia, ORCID: https://orcid.org/0000-0003-4731-1394450062, e-mail: umrko@mail.ru

Roman A. Bolotov, Acting Head of the South Ural Interregional Directorate of the South-Ural Interregional Directorate of the Federal Service for Supervision of Natural Resources Management of Russian Federation, Ufa, Republic of Bashkortostan, Russia, ORCID: https://orcid.org/0000-0001-6598-8126, e-mail: rpn02@rpn.gov.ru

Authors declare the absence of any competing interests.

Received:09.04.2021.

Revised: 28.04.2021.

Accepted: 14.05.2021. 